Jurnal Ilmiah

ILMU KOMPUTER

Universitas Udayana

Vol. XI, No. 1, April 2018

ISSN 1979 - 5661

\title{
PERANCANGAN DAN PEMBUATAN LUX METER DIGITAL BERBASIS SENSOR CAHAYA EL7900
}

\author{
I Made Satriya Wibawa ${ }^{1}$, I Ketut Putra ${ }^{2}$ \\ 1) Jurusan Fisika ,FMIPAUniversitas Udayana \\ Email: satriyawibawa66@yahoo.co.id \\ 2) Jurusan Fisika ,FMIPA Universitas Udayana \\ Email: putrajongrang@rocketmail.com
}

\begin{abstract}
ABSTRAK
Akan dibuat prototype alat lux meter digital berbasis sensor cahaya EL7900. Dengan menggunakan mikrokontroller R8C/13 sebagai unit proses dan tampilan hasil proses pada LCD. Unjuk kerja alat telah menunjukkan bahwa ada hubungan linier antara kebenaran tegangan output sensor dengan intensitas yang di tampilkan pada LCD. Kebenaran alat ini telah di kalibrasi dengan alat lux meter standar Hioki 3422 dan data menunjukkan bahwa intensitas yang di hasilkan oleh lux meter digital EL7900 berada pada range standar deviasi intensitas lux meter standar dengan kesalahan rata - rata sebesar 0,49 \%. Serta sensitivitas sensor EL7900 terletak pada daerah warna kuning.
\end{abstract}

Kata Kunci: Sensor EL7900, Microcontroller R8C/13, Lux Meter, Intensitas, Sensitivitas. Display

\section{ABSTRACT}

Please insert abstract here

Keywords:

\section{PENDAHULUAN}

Cahaya merupakan bagian dari spektrum gelombang elektromagnetik. Untuk mengetahui nilai intensitas cahaya di perlukan sebuah detektor cahaya. Detektor cahaya adalah detektor radiasi elektromagnetik dalam rentang spektral dari ultraviolet (UV) sampai inframerah. Detektor cahaya secara garis besar bisa dikatagorikan menjadi dua jenis yaitu detektor kuantum (quantum detector) dan detektor termal (thermal detector). Detektor kuantum beroperasi pada daerah ultraviolet sampai mid-infrared, sedangkan detektor termal seringkali digunakan pada daerah mid-infrared dan far-infrared. Prinsip kerja detektor kuantum zat padat (fotovoltaik dan fotokonduktif) didasari atas interaksi foton dengan sebuah bahan semikonduktor, sedangkan detektor termal bekerja dengan mendeteksi perubahan atau kenaikan temperatur. Beberapa jenis detektor kuantum adalah photodiode, phototransistor ,photoresistor. Pada skripsi ini menggunakan detektor photodioda.

Photodiode merupakan sensor optik semikonduktif. Prinsip dasar dari sebuah 
photodiode didasarkan atas proses yang disebut dengan photo-ionization. Di pasaran, tersedia banyak tipe dari photodiode dengan kemasan yang berlainan. Sensor cahaya EL7900 merupakan salah satu jenis photodiode yang bisa digunakan untuk mendeteksi intensitas cahaya dengan range 1 lux sampai 8000 lux. Photodiode EL7900 bekerja dengan cara mengubah energi cahaya yang diterimanya menjadi besaran listrik (arus) yang bisa dikonversi ketegangan dan di tampilkan dalam nilai digital, sehingga bisa diketahui berapa nilai suatu intensitas cahaya.

Sesuai dengan latar belakang tersebut di atas maka dirancang dan dibuat lux meter digital dengan sensor EL7900 untuk mengukur intensitas cahaya khususnya untuk cahaya tampak.

Dari latar belakang diatas maka dapat dirumuskan masalah sebagai berikut, pertama bagaimana rancangan rangkaian luxmeter digital berbasis sensor cahaya EL7900, kedua bagaimana sensitivitas dan respon spektrum sensor EL7900 sebagai sensor cahaya.

Tujuan dari penelitian ini adalah merancang dan membuat rangkaian luxmeter digital berbasis sensor cahaya EL7900 dan mengetahui sensitivitas dan respon spektrum EL7900 sebagai sensor cahaya.

Penelitian tentang perancangan dan pembuatan lux meter digital berbasis sensor cahaya EL7900 akan dibatasi pada beberapa hal, yaitu sumber cahaya yang digunakan adalah cahaya tampak dan Intensitas cahaya yang di deteksi dari 1 lux sampai dengan 8000 lux.

Manfaat dari hasil penelitian ini secara umum bagi masyarakat adalah alat ini dapat digunakan untuk menghitung intensitas cahaya tampak yang ada di tempat. Secara khusus bagi mahasiswa jurusan Fisika FMIPA Universitas
Udayana adalah dapat menambah ilmu pengetahuan mengenai sensor yang diaplikasikan sebagai pengukur intensitas cahaya tampak.

\section{TINJAUAN PUSTAKA}

\subsection{Photodiode}

Dioda semikonduktor secara luas telah digunakan dalam berbagai jenis aplikasi elektronika. Berbagai macam aplikasi dioda diantaranya digunakan sebagai rangkaian penyearah (rectifier), pengatur tegangan (dioda zener) dan dioda varaktor. Dioda pemancar cahaya (LED) sangat banyak digunakan untuk lampu indikator dan tampilan pada sebuah peralatan elektronika. Sebuah contoh penggunaan dari LED adalah sebagai peraga tujuh ruas (seven segment display). Sebagai penyearah atau LED, pemberian tegangan dilakukan dengan panjar maju (forward bias), dimana terminal positif sumber tegangan dihubungkan dengan bagian $\mathrm{P}$ (anoda) dan terminal negatif dihubungkan dengan bagian $\mathrm{N}$ (katoda). Pada dioda zener dan dioda varaktor, pemberian tegangan dilakukan sebaliknya atau dikenal dengan panjar undur (reversed bias).

Photodiode adalah sebuah piranti sambungan P-N yang dioperasikan dengan memberikan panjar mundur seperti disajikan pada gambar 2.1. Photodiode mempunyai sebuah "jendela" kecil transparan yang memberikan cahaya untuk mengenai sambungan P-N. Seperti pada dioda penyearah, pada photodiode juga berlaku jika diberikan panjar mundur akan mempunyai arus bocor (leakage current) yang sangat kecil. Arus akibat panjar balik ini dihasilkan oleh adanya pasangan elektron-hole pada daerah deplesi. 


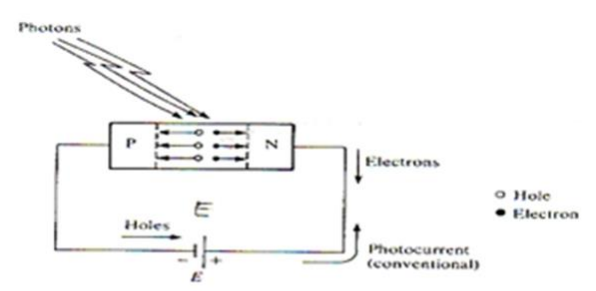

(a)

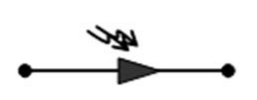

(b)

Gambar 2.1. Photodiode, (a) prinsip operasi dan (b) simbol

Pada photodiode, arus mundur (reverse current) ini bertambah sesuai dengan intensitas cahaya pada sambungan P-N tersebut. Jika tidak ada cahaya datang, reverse current $\left(I_{\square}\right)$ hampir bisa diabaikan dan disebut dengan arus gelap (dark current). Dengan meningkatnya intensitas cahaya yang datang akan menyebabkan peningkatan dari reverse current ini. Kurva karakteristik arustegangan (V-I) dari sebuah photodiode disajikan pada Gambar 2.2.

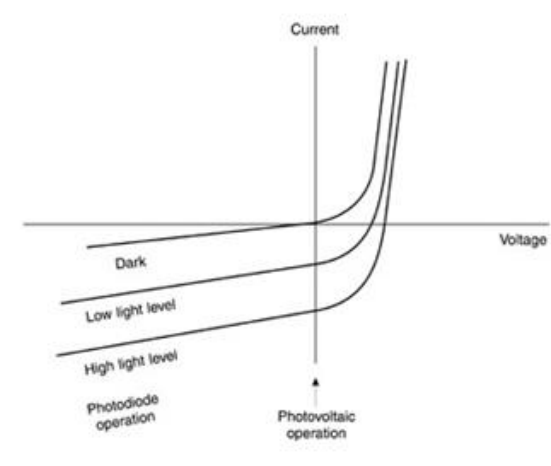

Gambar 2.2. Karakteristik $V-I$ sebuah photodiode

2.1.1 Prinsip deteksi cahaya pada photodiode

Prinsip deteksi cahaya dari sebuah photodiode dapat dipandang sebagai kebalikan dari LED. Secara diagram, proses ini ditunjukkan pada Gambar2.3. Photon diserap oleh atom yang menyebabkan sejumlah elektron berpindah dari tingkat valensi menuju tingkat konduksi dan yang tertinggal dalam pita valensi adalah lubang atau yang biasa disebut dengan hole. Proses terjadinya pasangan electron hole ini disebut dengan photogeneraiton. Perubahan energy yang terjadi pada elektron adalah $E_{\mathrm{g}}$ (energy gap), yaitu agar peristiwa ini terjadi, maka energi minimal yang dimiliki oleh photon adalah $E_{\mathrm{g}}$. Karena energi photon berkaitan dengan frekuensinya, maka nilai energi gap ini menentukan respon daerah spektral detektor cahaya. Detektor cahaya ini tidak merespon bila cahaya yang datang memiliki frekuensi lebih kecil dari frekuensi cut off $\left(f_{\mathrm{c}}\right)$ dimana $f_{\mathrm{c}}$ didefinisikan sebagai:

$f_{c}=E g / h$

$\mathrm{f}_{\mathrm{c}}=$ Frekuensi Cut Off $(\mathrm{Hz})$

$E=$ Energi Gap $(\mathrm{eV})_{\mathrm{g}}$

$h=$ Konstanta Planck $\left(6,261 \times 10^{-34}\right.$ J.s )

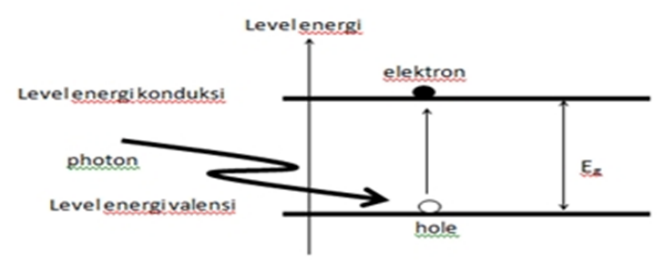

Gambar 2.3. Pembangkitan Pasangan Elektron-Hole

$\begin{array}{llll}\text { 2.1.2 } & \text { Respon spektral pothodiode } \\ & \text { EL7900 } & & \\ & \text { Photodiode EL7900 merupakan }\end{array}$ detektor cahaya yang mengubah intensitas cahaya menjadi arus listrik. Photodiode 
EL7900 dikemas dalam sebuah rangkaian terpadu (IC) yang didalamnya terdapat kombinasi dari sebuah photodiode dan sebuah penguat arus. Detektor ini mampu mendeteksi intensitas cahaya dengan range antara 1 lux sampai 8.000 lux dan memerlukan catu daya antara $2,7 \mathrm{~V}$ sampai 5,5 V. Pin asignment dan respon spektral dari photodiode EL7900 disajikan berturut-turut pada Gambar 2.4 dan 2.5.

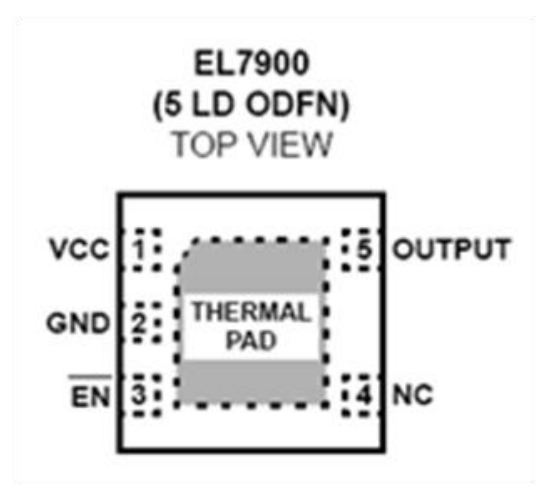

Gambar 2.4. Pin Signment

Photodiode EL7900

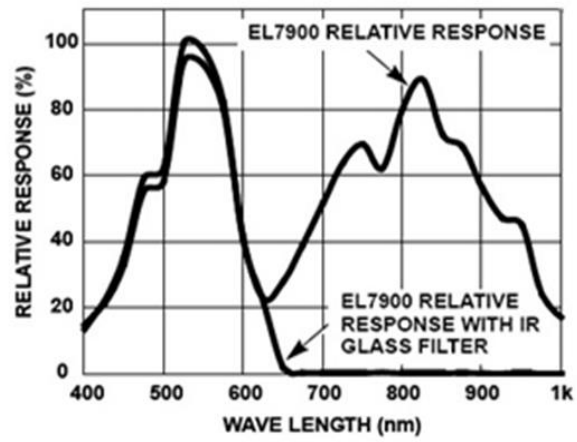

Gambar 2.5. Respon Spektral Photodiode EL7900

Gambar 2.5 menujukkan bahwa nilai respons relatif photodiode EL7900 berada pada kisaran panjang gelombang $800 \mathrm{~nm}$, sedangkan jika diberikan glass filter respon relatif optimum berada pada nilai $550 \mathrm{~nm}$.

\subsection{Mikrokontroler $\mathrm{R8C} / \mathbf{1 3}$}

Mikrokontroler berbentuk keping tunggal dimana di dalamnya terdapat CPU, memori, osilator clock, dan masukan/ keluaran yang dikemas dalam bentuk rangkaian terpadu. Sepertiu mumnya komputer, mikrokontroler merupakan alat yang mengerjakan instruksi-instruksi yang diberikan kepadanya, dimana instruksi-instruksi tersebut disusun dalam bentuk program komputer.

Arsitektur sebuah mikrokontroler terdiri dari tiga komponen utama, yaitu: Central Processing Unit (CPU), memori dan masukan/ keluaran.

a. Central Processing Unit (CPU)

CPU merupakan komponen yang berfungsi untuk mengorganisasi semua operasi yang terjadi di dalam mikrokontroler seperti operasi perpindahan data, operasi aritmatika dan logika, pengendalian piranti masukan/

keluaran dan seluruh sumber daya (recources) pada mikrokontroler. CPU terdiri atas tiga unit yaitu: Unit aritmatika dan logika (Arithmetic and Logic Unitl ALU), unit kontrol (Control Unit/ CU) dan register.

b. Memori

Memori merupakan komponen yang berfungsi untuk tempat menyimpan data dan program. Pada mikrokontroler terdapat dua jenis memori yang digunakan, yaitu memori data (RAM) dan memori program (ROM). RAM (Random Access Memory) adalah memori yang dapat dibaca atau ditulisi (Read/Write). RAM bersifat volatile karena data di dalamnya akan hilang jika catu daya dimatikan (turned off). ROM (Read Only Memory) adalah memori yang hanya dapat dibaca. ROM bersifat permanen karena data di dalamnya tidak akan hilang meskipun catu daya dimatikan.

c. Masukan/Keluaran

$$
\text { Piranti masukan/keluaran }
$$

adalah piranti yang diperlukan oleh mikrokontroler untuk 
berkomunikasi dengan dunia luar. Piranti masukan menyediakan informasi bagi ALU atau memori. Piranti masukan antara lain keyboard, keypad atau sensor. Piranti keluaran menyediakan data yang datang dari ALU atau memori serta untuk melaksanakan perintahperintah. Piranti keluaran antara lain peraga tujuh ruas (LED atau kristal cair) atau mekanisme pengendali seperti relay dan motor langkah.

Mikrokontroler R8C/Tiny series termasuk keluarga M16C, dan mempunyai beberapa seri antara lain $\mathrm{R} 8 \mathrm{C} / 10, \mathrm{R} 8 \mathrm{C} / 11, \mathrm{R} 8 \mathrm{C} / 12$. Masing masing seri berbeda dalam besarnya flash ROM dan jumlah pin I/O. Mikrokontroler yang digunakan pada penelitian ini adalah seri $\mathrm{R} 8 \mathrm{C} / 13$ dengan flash ROM sebesar $16 \mathrm{~Kb}$ dan RAM internal sebesar $1 \mathrm{~Kb}$. Mikrokontroler ini mempunyai beberapa kemampuan (fitur) yang menarik diantaranya:

a. Mempunyai 2KB In-System Programmable (ISP) Flash PEROM yang dapat digunakan untuk menyimpan program.

b. Tegangan operasi dinamis dari $4,0 \mathrm{~V}$ sampai 5,5 V.

c. Mempunyai Built-in ADC 10 bit 12 channel

d. Mempunyai I/O port sebanyak 32 line.

e. Mempunyai 3 timer 8 bit dan 1 timer 16 bit Built-in internal clock.

f. Mempunyai saluran serial full duplex.

g. Penulisan dan penghapusan program secara ISP yang fleksibel dan cepat.

Mikrokontroler R8C/13 dikemas dalam sebuah IC 32 kaki atau pin, dimana pin tersebut digunakan untuk keperluan port paralel 8-bit dua arah (bi-directional) yang dapat digunakan untuk berbagai keperluan (general purpose). Setiap port terdiri dari 8 pin sehingga terdapat 4 port, yaitu: port 0 , port 1 , port 2 , dan port 3. Konfigurasi pin pada mikrokontroler $\mathrm{R} 8 \mathrm{C} / 13$ ditunjukkan pada Gambar 2.6.

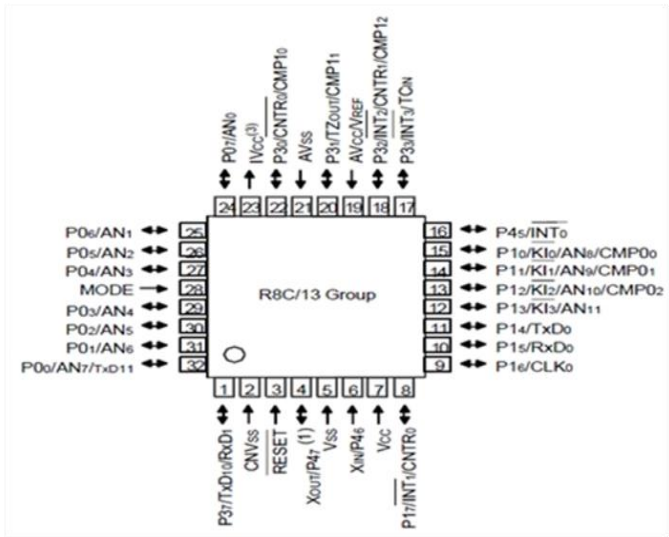

Gambar 2.6. Pin Asignment Mikrokontroler $\mathrm{R} 8 \mathrm{C} / 13$

Penjelasan serta fungsi masing-masing pin mikrokontroler R8C/13 ditunjukkan pada Tabel 2.1.

Tabel 2.1. Fungsi masing-masing pin mikrokontroler R8C/13

\begin{tabular}{|c|c|c|}
\hline No. Pin & Nama & Keterangan \\
\hline 7 dan 5 & Vcc, Vss & $\begin{array}{l}\text { Pin Vcc memberikan tegangan masukan } 2,7 \mathrm{~V} \\
\text { sampai } 5,5 \mathrm{~V} \text { dan Vss memberikan tegangan } \\
\text { masukan } 0 \mathrm{~V} \text {. }\end{array}$ \\
\hline 23 & IVcc & $\begin{array}{l}\text { Pin untuk menstabilkan catu daya internal, } \\
\text { Hubungkan pin ini ke Vss melalui kapasitor }(0,1 \\
\mu \mathrm{F}) \text {. }\end{array}$ \\
\hline $\begin{array}{c}19 \text { dan } \\
21\end{array}$ & $\mathrm{AVcc}, \mathrm{AVss}$ & $\begin{array}{l}\text { Pin untuk masukan catu daya } A / D \text { converter. } D \\
\text { huubungkan ke pin } A V c c \text { untuk Vcc. Hubungkan } \\
\text { pin AVss untuk Vss. Menghubungkan kapasitor } \\
\text { antara pin } A V c c \text { dan } A V s s .\end{array}$ \\
\hline 3 & RESET & Untuk mereset ulang. \\
\hline 2 & CNVss & Pin untuk Vss dihubungkan dengan resistor. \\
\hline 28 & MODE & Pin untuk Vcc dihubungkan dengan resistor. \\
\hline 6 & Xin & \multirow{2}{*}{$\begin{array}{l}\text { Pin ini disediakan untuk clock I/O rangkaian } \\
\text { keseluruhan. Menghubungkan resonator keramik } \\
\text { atau Kristal osilator antara Xin dan pin XOUT. }\end{array}$} \\
\hline 4 & Xout & \\
\hline $8,18,17$ & $\mathrm{INT}_{0}-\mathrm{INT}_{3}$ & Pin untuk masukan interupsi INT. \\
\hline $15,13,12$ & $\mathrm{KI}_{0}-\mathrm{KI}_{3}$ & Pin untuk masukan interupsi \\
\hline 8 & $\mathrm{CNTR}_{0}$ & Pin untuk $\mathrm{I} / \mathrm{O}$ timer $\mathrm{X}$. \\
\hline 18 & $\mathrm{CNTR}_{1}$ & Pin untuk $\mathrm{I} / \mathrm{O}$ timer $\mathrm{Y}$. \\
\hline 20 & TZout & Pin untuk keluaran $\mathrm{Z}$ timer. \\
\hline 17 & $\mathrm{TCin}$ & Pin untuk masukan $\mathrm{C}$ timer. \\
\hline $\begin{array}{l}15,14, \\
22,20\end{array}$ & $\begin{array}{l}\mathrm{CMPO}_{0} \text { to } \mathrm{CMPO}_{3} \\
\mathrm{CMP} 1_{0} \text { to } \mathrm{CMP}_{3}\end{array}$ & Pin untuk keluaran $\mathrm{C}$ timer \\
\hline 9 & $\mathrm{CLK}_{0}$ & Pin untuk transfer $\mathrm{I} / \mathrm{O}$. \\
\hline 10,1 & $\mathrm{RxD}_{0}, \mathrm{RxD}_{1}$ & Pin masukan data. \\
\hline 11,1 & $\begin{array}{l}\operatorname{TxD}_{0}, T_{x D_{10}} \\
\operatorname{TxD}_{11}\end{array}$ & Pin keluaran data. \\
\hline 19 & $V_{R E F}$ & $\begin{array}{l}\text { Pin untuk masukan tegangan referensi } \mathrm{A} / \mathrm{D} \\
\text { converter. Pin VREF Hubungkan pin untuk Vcc. }\end{array}$ \\
\hline 24,12 & $A \mathbb{N}_{0}$ to $A \mathbb{N}_{11}$ & Pin untuk masukan $A / D$ converter. \\
\hline 6,4 & $\mathrm{P}_{6}, \mathrm{P} 47$ & Pin untuk masukan \\
\hline
\end{tabular}




\subsection{Pengkonversi Analog ke Digital (Analog- Digital Converter /ADC)}

Analog to Digital Converters (ADC) merupakan sebuah piranti yang mampu menterjemahkan besaran analog (karakteristik umum dari setiap fenomena di "dunia nyata") menjadi bahasa digital (nilai diskrit) yang banyak dipergunakan pada pemrosesan data, komputasi dan sistem kontrol. Sebaliknya, piranti yang mampu mengubah bahasa digital kembali menjadi besaran analog disebut dengan Digital to Analog Converters (DAC). Definisi dan hubungan dari ADC dan DAC disajikan pada Gambar 2.7 (Walt Kester, 2004)

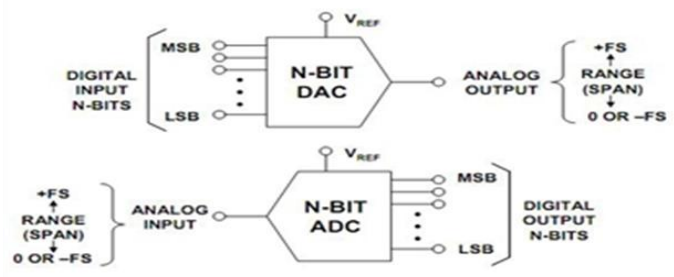

Gambar 2.7. Definisi Input dan Output ADC dan DAC

Transduser pada sensor akan mengubah tiap besaran yang diukur menjadi tegangan atau arus untuk diumpankan pada input analog sebuah ADC. Sebagai bagian dari proses ini, arus dan tegangan tersebut akan dinormalisasi pada rentang yang bersesuaian dengan rentang input $\mathrm{ADC}$ yang telah ditentukan. Perbandingan nilai diskrit yang bisa dihasilkan dibandingkan dengan rentang nilai input analog disebut resolusi. Nilai resolusi sebuah ADC atau DAC dinyatakan dalam bentuk bilangan biner dengan satuan bit, sehingga jumlah tingkatan nilai diskrit yang tersedia merupakan pangkat dua dari resolusi sebuah ADC. Misalkan pada ADC dengan resolusi 8 bit terdapat $2^{8}=256$ tingkatan nilai diskrit yang berarti mewakili rentang nilai dari 0 - 256 atau dari - 128 sampai 127 tergantung pada aplikasi yang dipergunakan. Resolusi tegangan sebuah ADC sama dengan jumlah rentang pengukuran seluruh tegangan dibagi dengan jumlah interval tegangan diskrit seperti ditunjukkan pada persamaan 2.5. Jika $\mathrm{N}$ menyatakan jumlah interval tegangan yang diberikan oleh $\mathrm{M}, \mathrm{M}$ adalah resolusi ADC dalam bit, maka hubungan antara $\mathrm{N}$ dan $\mathrm{M}$ diperoleh :

$\mathrm{N}=2^{\mathrm{M}}-1$

$\mathrm{N}=$ Jumlah interval tegangan.

$\mathrm{M}=$ Resolusi ADC (bit).

Resolusi ADC dalam satuan volt (Q) diperoleh dari :

$Q={ }^{E_{F S R}} / \mathrm{N}$

$Q \quad=$ Resolusi ADC (volt).

$\mathrm{E}_{\mathrm{FSR}}=$ Jumlah rentang pengukuran seluruh tegangan.

$\mathrm{N}=$ Jumlah interval tegangan.

$\begin{array}{cr}\text { Sedangkan nilai } & E_{F S R}(\text { jumlah } \\ \text { rentang pengukuran } & \text { seluruh } \\ \text { tegangan }) \text { didapatkan } & \text { melalui } \\ \text { pengurangan nilai tegangan } & \text { tertinggi } \\ \left(V_{\text {RefHi }}\right) \text { dan tegangan terendah } \\ \left(V_{\text {RefLow }) \text { yang dapat diukur oleh ADC. }} \text { Resolusi efektif yang }\right. \\ \text { sebenarnya pada sebuah data }\end{array}$
converter dibatasi pula oleh signal-tonoise ratio (SNR/perbandingan sinyal terhadap derau) yang bisa diperoleh dari sinyal yang telah didigitalisasi. Sebuah ADC hanya bisa mengubah sebuah sinyal masukan menjadi hanya beberapa bit tertentu dari nilai resolusinya, nilai ini disebut effective number of bits (ENOB). Tipe ADC berdasarkan responnya dibagi menjadi dua jenis, yaitu linear dan non-linear. Sebagian besar ADC bertipe linear, 
artinya nilai masukan memiliki hubungan linear dengan nilai keluarannya. Meskipun demikian, terkadang pada penerapannya keluaran ADC linear masih memungkinkan untuk menyimpang dari fungsi linear yang seharusnya. Hal ini bisa diatasi dengan melakukan kalibrasi atau dapat dicegah dengan melakukan serangkaian tes terlebih dahulu. ADC non-linear memiliki nilai masukan yang berhubungan secara logaritmik dengan nilai keluarannya.

Sinyal analog pada masukan sebuah ADC bersifat kontinyu terhadap waktu, oleh karena itu harus diubah menjadi nilai digital terlebih dahulu. Sebelumnya harus ditentukan besarnya laju pengambilan nilai digital dari sinyal analognya. Laju nilai digital ini disebut laju pencuplikan (sampling rate) atau frekuensi pencuplikan (sampling frequency). Pencuplikan ini diperlukan agar perubahan sinyal digital kembali menjadi analog dapat dilakukan dengan lebih sempurna.

Metode paling umum dari penerapan ADC adalah sebagai berikut:

a. Metode direct conversion $A D C$ atau flash $A D C$.

b. Metode Succesive Approximation $A D C$.

c. Metode ramp compare ADC.

d. Metode dual slope atau multi slope $A D C$, disebut juga integrating $A D C$.

e. Metode delta encoded $A D C$.

f. Metode pipeline ADC, disebut juga subranging quantizer.

g. Metode sigma delta $A D C$.

\subsection{Peraga Kristal Cair (Liquid Crystal Display/LCD) \\ LCD merupakan peraga elektronik} dengan material penyusunnya terdiri dari kristal cair yang bekerja dengan konsumsi daya listrik yang rendah, lebih rendah daripada LED. Pada umumnya, LCD bekerja dengan konsumsi daya listrik pada orde mikrowatt, sedangkan LED bekerja dengan konsumsi daya listrik pada orde miliwatt. Karakteristik inilah yang membuat LCD digunakan secara luas pada alat-alat yang menggunakan baterai seperti kalkulator dan jam tangan digital.

Material penyusun LCD terdiri dari kristal dengan struktur molekulnya berada diantara fase zat padat dan zat cair. Pada zat padat struktur molekulnya tersusun secara teratur dan posisinya tetap, sedangkan pada zat cair struktur molekulnya tidak teratur dan dapat bergerak bebas ke segala arah. Kristal ini mempunyai struktur molekul yang sama seperti zat padat, tetapi molekul penyusun kristal tersebut dapat bergerak bebas seperti pada zat cair jika diberikan penambahan temperatur. Sifat kristal tersebut menunjukkan sensitivitas yang tinggi terhadap temperatur dan menjadi dasar utama pemanfaatan kristal ini dalam teknologi LCD. LCD bekerja pada rentang temperatur yang terbatas, yakni dari $0 \square$ sampai $60 \square \mathrm{C}$.

Salah satu tipe LCD yang beredar di pasaran adalah seri M1632. Modul LCD dot matriks buatan Hitachi ini mempunyai dua baris penempatan karakter, dimana masing-masing baris dapat menampung sampai dengan 16 karakter. Diagram dari LCD seri M1632 serta fungsi masingmasing pin ditunjukkan berturut-turut pada Gambar 2.8 dan Tabel 2.2.

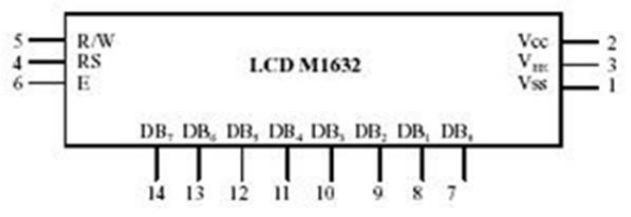

Gambar 2.8. Diagram dari Modul LCD Tipe M1632. 
Tabel 2.2. Fungsi pin-pin pada LCD Tipe M1632

\begin{tabular}{|c|c|c|l|}
\hline Pin no & Sinyal & I/O & \multicolumn{1}{|c|}{ Fungsi } \\
\hline 1 & VSS & Power & Ground \\
\hline 2 & VCC & Power & 2,7V sampai 5,5V \\
\hline 3 & VEE & Input & Penggerak LCD \\
\hline 4 & RS & Input & $\begin{array}{l}0: \text { Intruksi register (Write) dan } \\
\text { address counter (read) }\end{array}$ \\
\hline 5 & RW & Input & Memilih operasi write(0)read(1) \\
\hline 6 & E & Input & $\begin{array}{l}\text { Memilih operasi write/read } \\
\text { data }\end{array}$ \\
\hline $7 \ldots 10$ & DB3- DB0 & Input/Output & $\begin{array}{l}\text { Empat high data bus three state } \\
\text { bidirectional }\end{array}$ \\
\hline $11 \ldots 14$ & DB7-DB4 & Input/Output & $\begin{array}{l}\text { Empat high data bus three state } \\
\text { bidirectional }\end{array}$ \\
\hline
\end{tabular}

LCD M1632 mempunyai delapan jalur data (DB0 - DB7) dan tiga jalur kontrol (E, RS dan WR/ ). Penjelasan serta fungsi masing-masing jalur kontrol LCD dengan tipe M1632 adalah sebagai berikut (http://www.delta-electronic.com):

a. E adalah jalur Enable. Jalur ini digunakan untuk memberi tahu LCD bahwa pengguna akan berkomunikasi dengannya. Sebelum mengirim data ke LCD jalur ini dibuat berlogika tinggi terlebih dahulu. Data yang dikirim disiapkan pada jalur data, sehingga jalur $\mathrm{E}$ menjadi logika rendah. Transisi dari logika tinggi ke rendah ini akan memberitahukan LCD untuk mengambil data pada jalur kontrol dan jalur data.

b. RS adalah jalur Register Select. Pada saat jalur RS berlogika rendah, register yang diakses adalah register perintah, seperti perintah membersihkan layar (clear screen), posisi kursor dan lain-lain. Sedangkan jika berlogika tinggi, register yang diakses adalah register data, dalam hal ini adalah teks data yang harus ditampilkan pada layar.

c. R/W adalah jalur Read/Write. Pada saat jalur R/W berlogika rendah, informasi pada jalur data berupa pengiriman data ke LCD (Write). Sedangkan ketika pin WR/ berlogika tinggi, berarti sedang dilaksanakan pengambilan data dari LCD (Read).

\section{METODE PENELITIAN}

\subsection{Tempat dan Waktu}

Penelitian ini dilakukan di Laboratorium Gelombang dan Optik Jurusan Fisika, Fakultas Matematika dan Ilmu Pengetahuan Alam Universitas Udayana. Waktu penelitian dari bulan Maret 2011 sampai dengan Juni 2011.

\subsection{Peralatan dan Bahan Penelitian}

Dalam penelitian ini digunakan alat-alat sebagai berikut:

1. Mikrokontroller R8C/13

2. Resistor $10 \mathrm{k} \Omega, 33 \mathrm{k} \Omega, 22 \mathrm{k} \Omega, 64 \mathrm{k} \Omega$

3. Photodiode EL7900

4. Power supplay 5V

5. Crystal $20 \mathrm{MHz}$

6. Kapasitor $100 \mathrm{nF}, 33 \mathrm{pF}$.

7. LCD M1632

8. Papan PCB

\subsection{Pelaksanaan Penelitian}

\subsubsection{Perancangan dan Pembuatan Alat}

Lux meter digital adalah sebuah alat yang digunakan untuk mengukur intensitas cahaya dengan prinsip kerja mengubah intensitas cahaya yang datang menjadi arus listrik. Photodiode yang digunakan akan menangkap setiap sinyal cahaya yang di terimanya. Selanjutnya detektor cahaya tersebut akan menghasilkan keluaran berupa arus yang besarnya sesuai dengan intensitas cahaya yang diukur. Arus tersebut diubah ketegangan dan diperkuat oleh sebuah penguat awal, kemudian di umpankan pada mikrokontroler untuk dicacah dan hasilnya ditampilkan pada layar LCD. Digram blok lux meter digital berbasis sensor cahaya EL7900 disajikan 
pada Gambar 3.1, sedangkan diagram pengkabelan rangkaian (wiring diagram) disajikan pada Gambar 3.2.

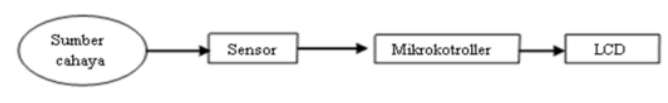

Gambar 3.1. Diagram Blok Prinsip Kerja Lux Meter Digital

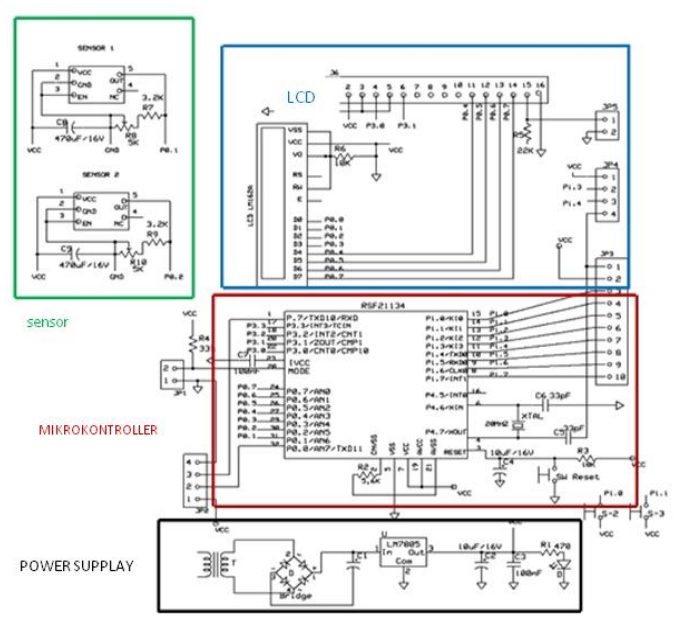

Gambar 3.2 Rangkaian Lux Meter dengan $\mathrm{R} 8 \mathrm{C} / 13$.

Agar alat bisa mencacah keluaran dari photodiode dan menampilkan nilai intensitas cahaya yang diterima, maka di butuhkan sebuah perangkat lunak untuk memprogram mikrokontroler. Diagram alir (flowchart) pemrograman mikroprosesor yang digunakan disajikan pada Gambar 3.3. Untuk megisikan file hex yang selesai dibuat ke dalam memori mikrokontroller AVR studio 4.

\subsubsection{Prosedur kalibrasi/pengujian alat} Sebelum dipergunakan alat harus melalui proses kalibrasi telebih dahulu.

Kalibrasi diperlukan untuk mengetahui sensitivitas alat dalam pengukuran. Kalibrasi awal yang dilakukan adalah dengan membandingkan nilai keluaran alat dengan sebuah pembanding/acuan. Peralatan disusun sedemikian rupa seperti pada Gambar 3.4. Pertama dihidupkan sumber cahaya tampak kemudian dihidupkan kedua lux meter, yaitu lux meter pembanding ( Hioki 3422) dengan lux meter rancangan (EL7900). Setelah itu catat masing- masing nilai yang di tampilkan pada LCD kedua lux meter tersebut. Hasil proses ini di catat pada tabel 3.1 .

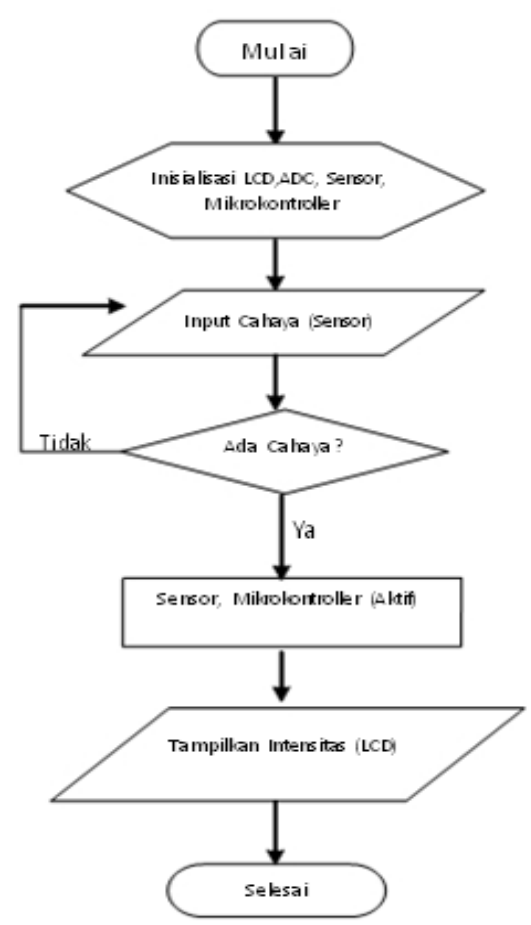

Gambar 3.3. Diagram Alir Program Menampilkan Nilai Intensitas

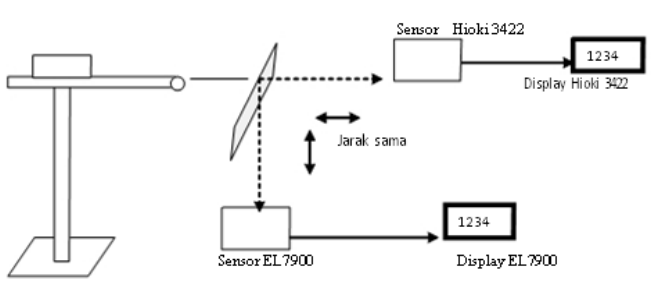

Gambar 3.4 Diagram blok pengujian alat untuk kalibrasi.

Langkah - langkah pengkalibrasian yang dilakukan dalam penelitian ini yaitu sebagai berikut : 
Setelah sensor dikalibrasi dan diperoleh data yang diinginkan, Selanjutnya melihat kelinieran input output antara intensitas yang ditampilkan LCD terhadap tegangan keluaran sensor dengan menggunakan persamaan regresi linear yaitu :

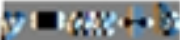

Dimana :

$\mathrm{y}=$ Intensitas yang di tampilkan pada

LCD ( lux )

$\mathrm{x}=$ Tegangan sensor $(\mathrm{mV})$

Nilai a dan b diperoleh dengan menngunakan persamaan :
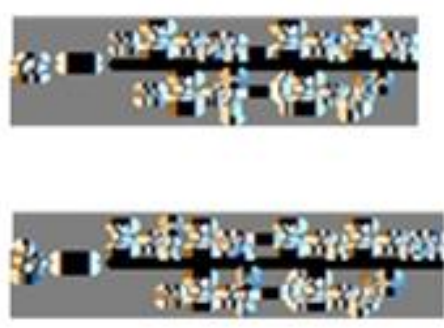

Tabel 3.1. Kalibrasi Galat/error

\begin{tabular}{|c|c|c|c|}
\hline Jarak(cm) & Eksperimen ke & Lux Meter Hioki 3422 (cm) & Lux Meter EL 7900 (lux) \\
\hline \multirow{5}{*}{225} & 1 & 148,1 & 148,1 \\
& 2 & 149 & 147 \\
& 3 & 148,1 & 148,1 \\
& 4 & 148,1 & 148,1 \\
& 5 & 148,1 & 148,1 \\
\hline & Rata-rata & 148,28 & 147,9 \\
\hline \multirow{6}{*}{250} & 1 & 96,7 & 96,7 \\
& 2 & 96,6 & 96,6 \\
& 3 & 96,7 & 96,6 \\
& 4 & 96,6 & 96,6 \\
& 5 & 96,7 & 96,6 \\
\hline & Rata-rata & 96,66 & 96,62 \\
\hline & & & \\
& & & \\
\hline
\end{tabular}

Kalibrasi berikutnya adalah mengetahui karakteristik sensor dengan menghitung sensitivitasnya. Pertama dihidupkan sumber cahaya, kemudian dihidupkan lux meter pembanding (Hioki 3422) dan lux meter rancangan (EL7900). Selanjutnya dicatat masing - masing nilai yang ditampilkan pada kedua lux meter dengan memberikan pajang gelombang yang berbeda - beda. Proses ini selengkapnya dapat disajikan pada tabel 3.2.
Tabel 3.2. Sensitivitas pengukuran intensitas untuk beberapa panjang gelombang

\begin{tabular}{|c|c|c|}
\hline \multirow{2}{*}{$\begin{array}{c}\text { Paniang Gelombang } \\
(\mathrm{nm})\end{array}$} & \multicolumn{2}{|c|}{ Intensitas (lux) } \\
\cline { 2 - 3 } & Lux Meter Hioki (3422) & Lux Meter EL7900 \\
\hline Biru & & \\
\hline Hijau & & \\
\hline Kuning & & \\
\hline Merah & & \\
\hline
\end{tabular}

\subsection{Analisa Data}

Dari data pada Tabel 3.1 dan 3.2, akan diplot grafik linearitas dan grafik respon spektral dari photodiode EL7900 seperti pada Gambar 3.5. Hasil-hasil yang diperoleh akan dianalisis untuk menjelaskan karakterisktik dari photodiode EL7900 tersebut.

\section{HASIL DAN PEMBAHASAN}

\subsection{Cara Kerja Alat}

Lux meter digital berbasiskan sensor cahaya EL7900 adalah suatu alat yang berfungsi untuk mengukur dan mengetahui nilai intensitas cahaya, dari suatu cahaya tampak yang dipancarkan ke sensor. Alat ini bekerja dengan cara mengirim sinyal data dari sensor 1 dan 2 yang terhubung masing-masing pada port 0.1 dan 0.2 pada mikrokontroller. Mikrokontoler yang juga berfungsi sebagai ADC kemudian akan menterjemahkan sinyal analog dari sensor menjadi data digital untuk diolah lebih lanjut oleh mikroprosesor. Perbedaan tegangan antara masukan sinyal pertama dan kedua , kedua dan ketiga dan seterusnya akan disimpan untuk kemudian dibandingkan oleh mikrokontroller R8C/Tiny sesuai dengan program pada mikrokontroller. Selisih tegangan tersebut kemudian dibagi dengan 0,00488 untuk memperoleh nilai intensitas dan akan ditampilkan pada LCD M1632 yang terhubung melalui port DB3DB0 dan port DB7-DB4. 
Adapun petunjuk penggunaan (manual) dari alat ini adalah sebagai berikut :

1. Nyalakan alat dengan menghidupkan catu daya.

2. Ketika dinyalakan, tampilan pada LCD akan menunjukkan nilai 0 .

3. Arahkan sensor pada sumber cahaya yang akan diukur nilai intensitas

cahayanya.

4 Tekan saklar skala untuk menentukan nilai batas maksimum yang akan di gunakan misalkan skala 10,200 atau 500 .

5. Hasil pengukuran nilai intensitas cahaya terakhir akan disimpan dan ditampilkan pada layar LCD.

\subsection{Pembahasan Hardware dan Software Interface}

Software atau perangkat lunak dari Lux Meter Digital berbasiskan sensor EL7900 dirancang menggunakan bahasa $\mathrm{C}$ dengan menggunakan software IDE sebagai antarmuka serta $\mathrm{C}$ Compiler Hew sebagai compiler bahasa $\mathrm{C}$ untuk IDE. Software dari alat ini dirancang sesuai dengan diagram alir pada Bab III Gambar 3.3.

a. Sensor Cahaya EL7900

Sensor Cahaya EL7900 dihubungkan ke port 0.1 dan 0.2 pada sistem minimum mikrokontroller R8C/Tiny. Ketika catu daya on, mikrokontroller akan mengalirkan sinyal berupa tegangan melalui pin 7 . Tegangan ini akan mengaktifkan sensor EL7900 sehingga bagian penerima dari sensor EL7900 akan menangkap cahaya tampak yang kemudian terjadi proses fotolistrik. Sensor EL7900 selanjutnya akan mengalirkan sinyal berupa data analog menuju port 0.1 dan 0.2 yang telah difungsikan sebagai pin ADC sebelumnya pada proses inisialisasi program. Data analog akan diubah secara langsung menjadi data digital oleh mikrokontroller sebelum diolah lebih lanjut.

Berikut potongan listing program untuk proses inisialisasi ADC :

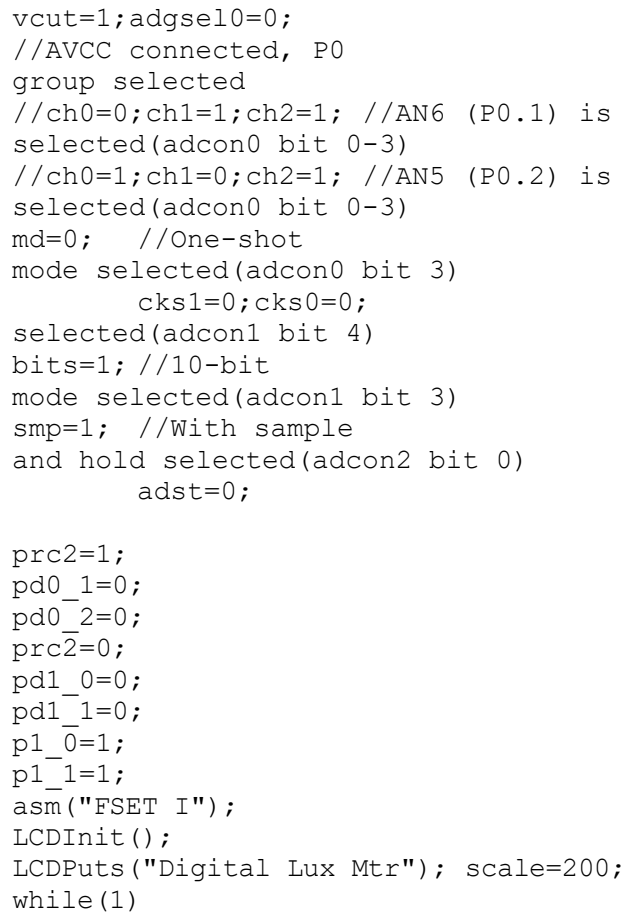

\section{b. LCD M1632}

LCD tipe M1632 dihubungkan ke 7 pin pada mikrokontroler R8C/Tiny, yakni 4 pin dari port PD0 sampai dengan port PD3 untuk jalur data dan 3 pin dari port PC5, PD4 dan PD5 untuk jalur kontrol,sedangkan pin $\mathrm{PC} 4$ digunakan untuk pengaturan nilai kontras layar LCD. Dalam penelitian ini LCD yang digunakan dalam mode 8 bit. Hal ini untuk menyesuaikan jumlah pin yang di gunakan untuk jalur data. Adapun listing program untuk 
proses inisialisasi LCD adalah sebagai berikut:

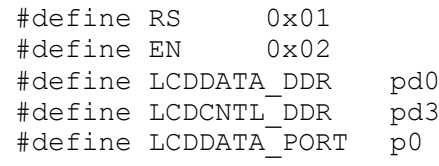

Sedangkan potongan listing program di bawah ini untuk pendefinisian fungsi pin LCD :

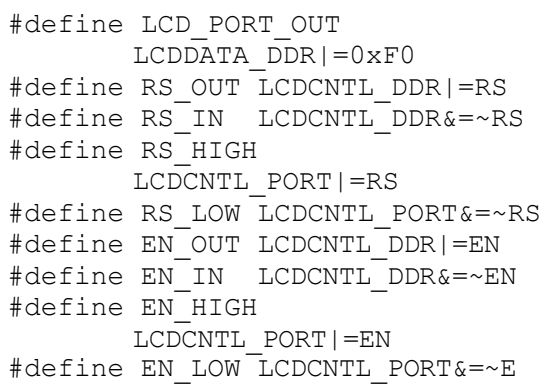

\subsection{Pengujian Alat}

Pengujian alat dilakukan untuk mengetahui ketepatan serta sensitivitas alat. Pembahasan pengujian alat meliputi kelinieran input-output, pengkalibrasian alat serta pengujian sensitivitas.

\subsubsection{Hasil kelinieran input-output (untuk} kerja alat)

Untuk mengetahui kelinieran nilai pada alat telah dilakukan kalibrasi pada rangkaian antara tegangan output catu daya, tegangan output sensor dan intensitasnya di display pada LCD dengan hasil seperti pada tabel 4.1 .

Tabel 4.1 Tabel Linieritas InputOutput Tegangan Catu Daya, Sensor dan Display LCD.

\begin{tabular}{|c|c|c|c|}
\hline No & $\begin{array}{c}\text { Tegangan Catu Daya } \\
\text { (Volt) }\end{array}$ & $\begin{array}{c}\text { Nilai Rata - Rata Ouput } \\
\text { Tegangan Sensor (mV) }\end{array}$ & $\begin{array}{c}\text { Nilai Rata-Rata } \\
\text { Display LCD (lux) }\end{array}$ \\
\hline 1 & $5 \mathrm{~V}$ & 0 & 0 \\
\hline 2 & $7 \mathrm{~V}$ & 10,7 & 4,32 \\
\hline 3 & $9 \mathrm{~V}$ & 26,7 & 11,4 \\
\hline 4 & $11 \mathrm{~V}$ & 46,4 & 23,3 \\
\hline 5 & $13 \mathrm{~V}$ & 73,3 & 33,7 \\
\hline 6 & $15 \mathrm{~V}$ & 95,4 & 42,6 \\
\hline
\end{tabular}

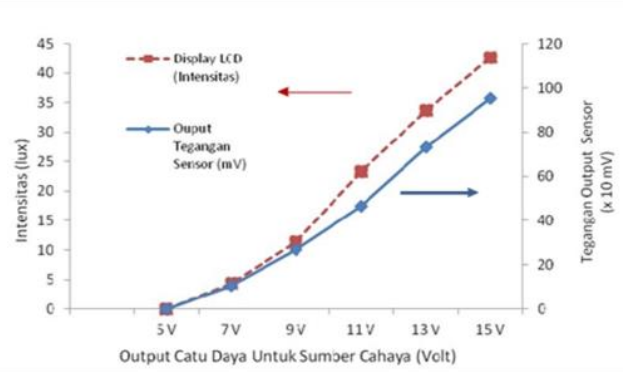

Gambar 4.1. Grafik Kesesuaian Input-

Output Tegangan Catu Daya dari Sumber

Cahaya, Sensor dan Display LCD

Hasilnya di tampilkan pada grafik 4.2. dengan $y$ merupakan besarnya intensitas dan $x$ sebagai nilai tegangan output sensor di peroleh persamaan :

$y=0,4559 x+0,0349$

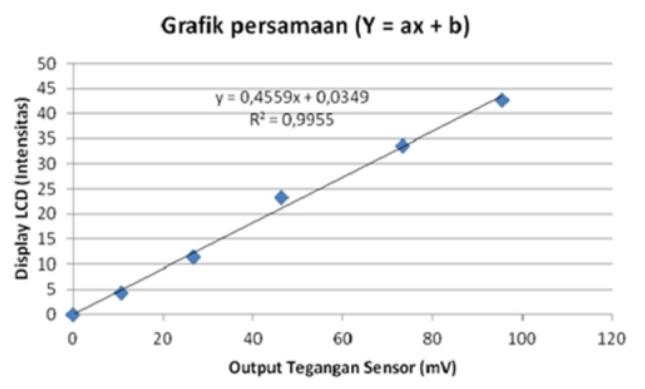

Gambar 4.2. Grafik Regresi Linier Intensitas Display LCD Terhadap InputOutput Tegangan Sensor.

Berdasarkan grafik pada gambar 4.2., terlihat bahwa intensitas yang ditmpilkan pada LCD berbanding lurus dengan tegangan output sensor.

\subsubsection{Hasil Kalibrasi Alat.}

Kalibrasi alat dilakukan dengan cara membandingkan nilai intensitas yang di catat oleh lux meter standar (Hioki 3422) dengan intensitas yang di catat oleh lux meter digital EL 7900. Langkah untuk kalibrasi alat dilakukan sesuai dengan langkah pada BAB III bagian 3.1. Setelah dilakukan pengujian alat sebanyak 5 kali untuk masing- masing variabel jarak 
didapatkan hasil pada Tabel 4.2 dan diplot pada gambar 4.3. :

Tabel 4.2. Tabel Intensitas Rata-rata Sebagai Fungsi Jarak

\begin{tabular}{|c|c|c|c|}
\hline NO & Jarak(cm) & $\begin{array}{c}\text { IntensitasRata-rata } \\
\text { Hi (lux) }\end{array}$ & $\begin{array}{c}\text { Intensitas Rata-rata } \\
\text { EL (lux) }\end{array}$ \\
\hline 1 & 225 & 148,28 & 147,8 \\
\hline 2 & 250 & 96,66 & 96,63 \\
\hline 3 & 275 & 86,72 & 86,06 \\
\hline 4 & 300 & 78,46 & 77,07 \\
\hline 5 & 325 & 71,18 & 68,84 \\
\hline 6 & 350 & 61,58 & 62,54 \\
\hline 7 & 375 & 52,42 & 52,62 \\
\hline 8 & 400 & 44,27 & 44,32 \\
\hline
\end{tabular}

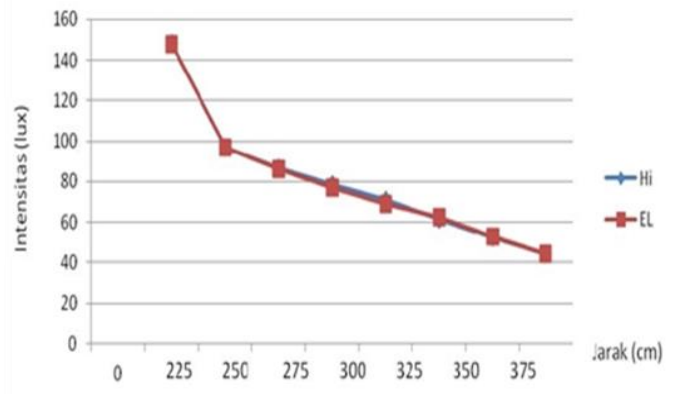

Gambar 4.3 Grafik Intensitas Sebagai Fungsi Jarak

Gambar $\quad 4.3$ menunjukkan hubungan antara intensitas cahaya rata rata yang terdektesi oleh lux meter standar (Hi) dan lux meter buatan (EL) fungsi jarak. Berdasarkan grafik tersebut intensitas yang di ukur baik dengan lux meter standar Hi maupun EL adalah sama. Namun bila di perhatikan data pada lampiran 1.a dan 1.b, ternyata ada kesalahan rata - rata $0,49 \%$. Lux meter EL lebih rendah di banding dengan lux meter standar Hi. Kesalahan ini cukup kecil sehingga grafik tampak berimpit. Berdasarkan hasil standar deviasi pada lampiran 1, bahwa hasil intensitas dari EL7900 berada pada range standar deviasi dari Hi 3422. Gambar 4.3 juga menunjukkan adanya loncatan intensitas baik yang diukur oleh lux meter Hi maupun EL, yaitu pada jarak kurang dari $250 \mathrm{~cm}$ dari sumber lampu 40 watt, tegangan 220 Volt. Ini menunjukkan nilai intensitas cahaya berbanding terbalik dengan jarak kuadrat dari sumber. Sehingga semakin dekat dari sumber intensitasnya naik secara kuadratik.
4.3.3. Hasil Karakterisasi Sensor EL 7900 Pengujian sensitivitas dilakukan dengan mengubah jarak antara sensor dengan sumber cahaya dan mengganti-ganti warna filter gelombang. Hasil rata- rata pengujian pada masing-masing titik dengan empat filter warna yang berbeda seperti di tunjukkan pada lampiran 2. Dari beberapa titik tersebut diambil satu titik untuk mewakilinya yaitu tegangan $=13$ Volt dengan jarak $=75 \mathrm{~cm}$ disertai dengan empat filter warna di dapatkan hasil pada tabel 4.3 dan diplot pada grafik 4.4. rendah dari filter warna biru, ini disebabkan karena pengaruh beberapa komponen alat baik dari segi karakteristik sensor maupun komponen yang lainya. Untuk filter warna merah menunjukkan nilai intensitas $\mathrm{Hi}=1$ lux dan $E L=0,2$ lux merupakan nilai terendah.

Tabel 4.3. Tabel Uji Sensitivitas, Tegangan Sensor Cahaya (V = 13 volt), $\operatorname{Jarak}(\mathrm{S}=75 \mathrm{~cm})$

\begin{tabular}{|c|c|c|}
\hline Warna & Hi(lux) & EL (lux) \\
\hline Biru & 3,36 & 6,64 \\
\hline Hijaut & 3,36 & 3,74 \\
\hline Kuning & 6,72 & 5,88 \\
\hline Merah & 1 & 0,2 \\
\hline
\end{tabular}

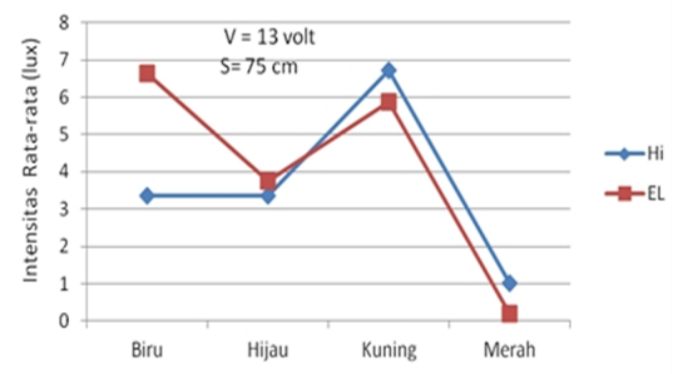

Gambar 4.4 Grafik Uji sensitivitas

\subsubsection{Hasil Kelinieran Sensor EL 7900 \\ Pengujian kelinieran dilakukan} dengan cara mengambil salah satu warna dari empat filter gelombang yakni warna 
kuning dengan memberikan tegangan sumber cahaya yang berubah-ubah dan hasilnya seperti tampak pada tabel 4.4 dan grafik 4.5. Grafik 4.5. menunjukkan semakin besar tegangan sumber yang di berikan, semakin besar pula nilai intensitas yang terbaca oleh lux meter Hioki maupun EL7900. Ini menggambarkan kelinieran antara lux meter Hioki dengan lux meter EL7900.

Tabel 4.4. Tabel Linieritas Warna Kuning
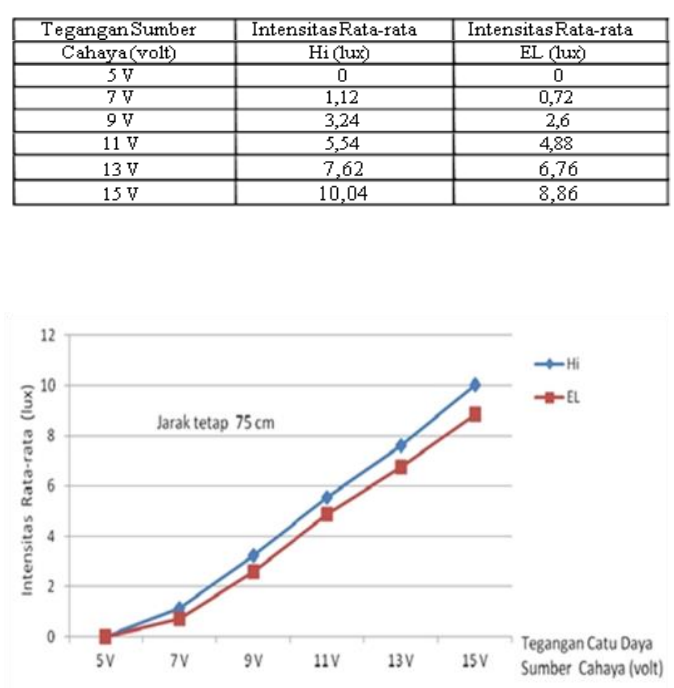

Gambar 4.5. Grafik Linieritas Warna

\section{PENUTUP}

Dari hasil penelitian yang dilakukan dapat di ambil beberapa kesimpulan, antara lain :

1. Telah berhasil dibuat sebuah alat lux meter digital berbasis sensor cahaya EL7900 dengan menggunakan dua sensor EL7900 dan dua display pada satu LCD yang linier dengan lux meter standar Hioki 3422.

2. Lux meter EL7900 mempunyai sensitivitas yang mendekati sama dengan lux meter standar (Hioki 3422) dengan nilai kesalahan $0,49 \%$, dan berada pada range standar deviasi dari lux meter standar.

3. Lux meter EL7900 mempunyai respon paling tinggi pada filter warna kuning. 